\title{
Normative and Practical Aspects Related to the Causes of Dissolution of Marriage in Roman
}

\author{
Sulejman Ahmedi, Ph. D. Cand. \\ Republic of Macedonia, State University of Tetova - Faculty of Law
}

\section{Abstract}

The research includes the analysis of the causes for divorce in Roman law and how to regulate the dissolution of marriage through legal provisions. Divorce and marriage are ancient institutions of matrimonial and family law, which countries from the ancient times had this as a trend for their regulation through legal provisions. Many principles and rules of Roman law are adopted also from the legal systems of many countries of the modern world, in order to unify their own private national law. This trend is particularly noticeable in the states member of the European Union, which refers to IUS COMUNE, which simultaneously is the common basis of legal practice worldwide. Roman jurists work techniques present a model with permanent value for legal doctrine and jurisprudence of many countries when it comes to the practical operation of law and its social needs adjustment. In Roman law the dissolution of marriage recognized since LEX IULIA DE ADULTERIIS, the law issued during the reign of Augustus in year $18 \mathrm{BC}$, which had defined and has codify the oldest rate of self-righteousness. Through this lex-of (the law) was removed from the hand of the affected family an important part of ascertaining of adultery and the punishment of preparations by treating it through public bodies. Fill into this form he found in Corpus luris Civilis and has exerted influence on marriage in Europe until the modern age. Dissolution of marriage was also provided by the law of XII tables approved in year $450 \mathrm{BC}$. In the research are analyzed the ways of divorce under the Roman law, which were: Divorce without the willpower of the spouses, or because of natural events and Divorce by willpower of the spouses or known as divorce caused by human actions. In the post-classic period, due to changes in moral views who brought Christianity, emperors decide religious provisions on divorce. At this time there were two basic types of marriage dissolution: Divortium cum damno, or divorce followed with bad consequences, and Divortium sine damno, or divorce without bad consequences.

Keywords: Family, Divorce; Life apart; and reasons for divorce.

\section{Introduction}

About the chosen topic I will give an explanation about the classification of roman citizens and the concept of marriage, to have a clearer picture of the man and woman's status in roman family and society.

\section{Sui juris persons and persons alien juris}

On the basis of the legal position of the family, roman citizens were divided in sui juris persons and alien juris persons. Since the law of XII tables, as persons sui juris considered all persons of male and female gender, who enjoyed status libertatis and status civitatis, where upon them it was not located the power of the father or the husband (patria potestas, manus) ${ }^{1}$. Alieni Juris persons considered all persons regardless of gender and age, and regardless those enjoyed the status civitatis or libertatis. When on them it was located the head of the family power as the man power (manus), either as the power of the father (patria potestas). This statutory division of Roman citizens was characteristic of the Roman patriarchal family. The roots of this division first emerged when it was established the patriarchal find, because of the natural division of labor between men and women which brought,,Historic defeat of the female sex". Pater familias was the only person sui juris, while all the others, family members, were alien juris persons or persons of foreign law. In ancient right after marriage the wife become alien juris person, which was subject to the orders of pater familias in the husband's family. In the classic and post-classic right, lost the direct dependence of women in the husband's family on pater familias. For this

${ }^{1}$ Dr. Ivo Puhan, Roman Law, Pristina, fifth edition, pg.174 
time was worth the definition: "marriage is a relationship between man and women and the whole community of life, mutual separation of divine and human justice". Likewise marriage it took the definition as: "marriage is the bond between husband and wife, which constitutes the community of inherent life". Therefore in Roman law marriage was community of monogamous life which was regulated by the legal provisions between man and women. Lawyer Gai has filed a case on the relationship between sui juris persons and alien juris persons. Gai lessons on relationship between alien juris persons and sui juris mainly include 3 basic groups of issues:

Issues on relationships between the husband and wife (matrimonial law);

Issues on the relationship between father as the head of the patria potestas and the children, mainly persons who were under the patria potestas (the paternal rights), and

Group issues on completing the ability to act of sui juris persons, who due to lack of maturity, because of their gender or because of their mental, moral and physical defects, their capacity to act were, limited (custody law).

\section{Dissolution of marriage}

Under the provisions of the Roman law, marriage can be dissolved exclusively by the action of the new legal facts:

Natural events and

Human actions

Dissolution of marriage due to natural events: the death of one spouse and for deminutio capitis. ${ }^{1}$

Natural death of the husband, the wife or both spouses cause the dissolution of the marriage as well as the causing lost of the legal ability. After the death of one spouse, the marriage barriers fell down due to the existence of the marital relationship. In that case, men can immediately associate new marriage, while for women was set tempus lugendi. ${ }^{2}$ Marriage was solved also in all cases where any roman citizen suffer capitis deminutio maxima-loss of freedom and capitis deminutio media-loss of citizenship, because both of the institutions were related to the loss of the citizen status, including also the loss of jus conubii. ${ }^{3}$

\section{Dissolution of marriage by divorce}

In ancient law was allowed dissolution of marriage by divorce which did not depend on the court's decision, as it was in the contemporary right. This was based on the preliminary legal act with whom marriage become and it was called the actus contrius that means contracts act. This was exclusively the right of the husband and the right of the pater familias in husbands family. Dissolution of marriage was allowed because of adultery, because of alcoholism, due to miscarriage, etc. The woman had no such right, because this wasn't allowed by position in the family as an alien juris person. Correlative form of divorce was final connection to: marriage connected with a religious ceremony- conferatio, and it was solved by differatio form, said better before the clergy; while marriage when the wife on the occasion was considered daughter of the husband's family- usus, was solved by real dissolution of marriage in order of her husband. In ancient Roman law, at the time of Romulus was allowed dissolution of marriage, but only as a husband's right and in his favor. It was known the unilateral dissolution of marriage with the husband's will, with - manus. The husband at any time had the right to remove from the marriage his wife with what before the family court, he presented the reasons of dissolution of marriage and if his main reasons were serious, he had the right to evict his wife and hole the miraze. As result of this kind of dissolution of marriage, happened that the wife was "sold" as an family girl of the preliminary marriage based on the purchase of the girl, in the marriage where dominated the husband with manus or the preliminary marriage this was related to the common life, between the girl and the boy for one (1) year term. Normally such a divorce is done by the husband's side. In this, the wife had no role. In reality this was a rejection of the wife by the husband's side, instead of the ordinary dissolution of marriage.

\footnotetext{
${ }^{1}$ Reduction of rights, change the prior status of a person.

2 Bereavement, serving to avoid blood-commixti sanguinis, respectively suspicion of paternity if the woman was pregnant at the time when the other spouse died.

${ }^{3}$ Possibility of marriage between persons belonging to different layers
} 
This way of marriage dissolution was not considered if the husband understood about the wife's betrayal who was with manus. In this case he had ius acidendi, called the right to murder. ${ }^{1}$ In the law of XII tables which also represents the first Latin legal document written since 2500 years, in Table IV point 3 Cicero quotes (phil. 2,28,69,) "Illam suam res sibi habere iussit ex XII tab., claves ademit, exxgit". By this we get to know that the right to resolve the unilaterally marriage belongs only to the husband. Legal form was: husband orders his wife to pack up (effects) of its own, hand over the keys of the husband's house and other facilities, and leave the domus -his house. Later dissolution of marriage other than in the manus it was recognized the right of the women to demand the dissolution of marriage and these marriages were recognized as marriages without manus, positively without the power of the husband. Also is allowed dissolution of marriage by mutual consent of the spouses. For very reasonable reasons dissolution of marriage could be asked even by the pater familias of the wife. The reasons for divorce were not certain. Dissolution of marriage could be done even when there are no main reasons, except the desire of the one spouse. Provided form of dissolution of marriage was estimated as a declaration before witnesses or written libellus repudii and it was free from any religious element. The only requirement that was necessary for the validity of marriage was deductio uxoris in damum mariti ${ }^{2}$, and the desire of spouses in marriage to belong to the same class and to have children together.

There were no legitimate courts, to prevent divorce without reason. Although later brought several financial norms that bind the parties, but e this had no effect. Later in the period from 134 BC until the arrival of Constantine, the marriage could be resolved very easily, which led to the increasing number of divorces. Marriage was considered resolved if the husband leaved his first wife and married again with another, or if only informally stated his desire to divorce. Thus, marriage could be resolved by unilateral request and desire - repudium- and with agreement of both spouses -communi consensus. In the post-classic right, especially during the reign of Emperor Constantine due to changes in moral views who brought Christianity, they brought religious provisions due to dissolution of marriage and increased influence of Christian doctrine, which declined quite number of divorces. He noted that- "Marriage convinced by both spouses cannot be resolved in the same way". ${ }^{3}$ Constantine raised again the death penalty for a woman who did not remain faithful to her husband, and it was considered as one of the most serious causes that affect the dissolution of marriage. On the other hand, he acknowledged the woman who has a husband soldier the right to demand dissolution of the marriage, if he was absent for a period of five (5) year.

At this time there were two basic types of divorce:

Divortium cum damno- or divorce followed with bad consequences, and

Divortium sine damno- or divorce without bad consequences.

Divorce followed by bad consequences divided into two types:

- In divorce without cause provided legal and,

- Unilateral divorce with the fault of one of the spouses.

Harmful consequences that struck one spouse to blame for dissolution of marriage with bad consequences was: loss of dowry, the new marriage ban, deportation.

Divorce without bad consequences divided into two types:

- Divorce by mutual consent of the spouses, and

- Divorces by the spouses will but only for justifiable reasons such: impotence, sexual diseases etc.

\footnotetext{
${ }^{1}$ Although the right of divorce was the first since the Romulus and the Law of XII tables, as the first dissolution of marriage in ancient Rome recognized Antonijusa Lucijusa divorced in $447 \mathrm{BC}$, which has expelled from the marriage his wife.

2 Going woman in her husband's house.

${ }^{3}$ Marko M., divorce and causes for divorce, page.55
} 
The causes that gave rights to the innocent spouse to dissolve the marriage without any harmful consequences were: adultery, serious criminal offenses, endangering life, immoral life, etc.

The form of dissolution of marriage was the written statement before witnesses! With the advent of Justinijanus in power, there were changed and codified many laws, as well as provisions for dissolution of marriage which were taken as basis by many other state legislators, especially in the territory of Byzantium and Russia. According to him, dissolution of marriage is not obligation only for the husband, but this is one of his rights and according to this, he again recognized the right of dissolution of marriage with the agreement of both spouses. He also foresaw lighter sentences for the woman who betrayed her husband and her accomplices. As reasons that could be basis for dissolution of marriage are: the inability of one of the spouses within three (3) years, if one spouses converted into slave, soldier husband's absence, if the wife did not remain faithful to her husband, etc.

\section{CONCLUSION}

After analyzing the concept of marriage and its dissolution in Roman law, we can conclude that the regulation of their causes that led to dissolution of marriage and the ways envisaged by the laws of that time are the result of social order to that period. Thus we see that in ancient Roman law, when man had power over wife-with manus, the right to dissolve the marriage had only the husband, while the wife had even no family or property rights. Later in the classic right when overpowered marriages without manus, the basic principle of Roman law on the issue of relations between spouses in this period said "libera matrimonia esse debent "-marriage should be free! The application of the principles referred to the dissolution of marriage, enabled dissolution of marriage to be done with decision by the husband or with the decision of the wife, also with mutual relationship of the spouses. Practice form of dissolution of marriage was the first statement written before the witness written- libelous repudio. In the post-classic right, for different reasons in moral views who brought Christianity, the emperor's created strict rules on dissolution of marriage, since marriage was considered sacred and once if it was connected, it couldn't be broken except by death. While the arrival of Justian in power, it sensitized once again the issue of dissolution of marriage, and it was recognized again the dissolution of marriage with the agreement by the spouses. The wife again won the right to demand the dissolution of marriage, the family and property rights who belong to her as a result of dissolution of marriage. The study of Roman law in general and special rules governing the right institutions and social relations, it is of particular importance for any jurist since it teaches us the historical development of the states and justice and also the legal language which even today is a general terminology in the appointment of many concepts, institutions, legal principles.

\section{BIBLIOGRAPHY}

[1] Divorce and causes for divorce, Marko Mladenovic, Belgrade, 1974.

[2] Istituzioni di diritto romano, Vincienzo Arangio-Ruiz, 1957,

[3] La famiglia romana, Carla Fayer,

[4] Lex duodecim tabularum-legal relations, regulated by Law of XII tables, Dr. Musli Halimi, Tetovo 2004,

[5] Roman law, Dr. Ivo Puhan, fifth edition, Pristina, 